\title{
PENGARUH UMUR KEHAMILAN, TINGKAT PENGETAHUAN TENTANG MENYIKAT GIGI, TERHADAP DERAJAT KEBERSIHAN GIGI DAN MULUT PADA IBU HAMIL DI KELURAHAN BINTORO KABUPATEN DEMAK
}

\author{
Bedjo Santoso*), Bambang Sutomo**) \\ bedjosantoso27@gmail.com
}

\begin{abstract}
In order to realize the development of health, oral health as an integral part of the whole human health. Pregnant women are one of the vulnerable groups care of oral health care. In the event of pregnancy, occurring patterns of change in the maintenance of oral hygiene becomes worse. These changes are caused by hormonal changes that marked the onset of nausea, vomiting, feeling of fear when brushing your teeth. The results of a preliminary study on 10 pregnant women in Sub Bintoro randomly during routine activities posyandu average values obtained OHI-S is 3.3 (poor category). It also obtained data indicating maternal knowledge about how to brush teeth still low. This study aims to determine the effect of gestational age, the level of knowledge about brushing teeth, the degree of oral hygiene in pregnant women in Sub Bintoro.

This type of research is quantitative descriptive cross sectional survey research approach. The population of pregnant women Bintoro Village, District Demak, Demak which amounted to 80 people. Sampling was done Proportional stratified random sampling method, a number of 55 people. The data were analyzed by descriptive quantitative, with the Spearman rank correlation test, regression test sdan with linear regression.

The results showed maternal gestational age mostly in the third trimester of 29 people $(52.7 \%)$, the level of knowledge in good condition category 40 people $(60.6 \%)$, the degree of oral hygiene pregnant women mostly in the category of OHI-S are 25 persons $(37.9 \%)$. There is a significant relationship between the degree of knowledge of dental and oral hygiene, according to the results with the Spearman rank correlation test with CI 95\% $(\alpha=0.05)$, obtained p.value $=0.000$. There is a significant effect on the degree of knowledge of dental and oral hygiene, according to the results of linear regression test with $\mathrm{CI}=95 \%(\alpha=$ 0.05 ), obtained p.value $=0.000$. Pregnant women are advised to maintain and increase the maintenance of dental hygiene at all stages of gestation, following the extension of activities by health personnel, maintaining and improving ways of maintaining oral hygiene.
\end{abstract}

Keywords : knowledge, pregnancy, oral hygiene (Ohis)

*), **) Lecturer Department of Nursing Dentistry Polytechnic MoH Semarang 
Kesehatan gigi dan mulut sebagai bagian yang tidak terpisahkan dari pembangunan kesehatan secara menyeluruh dan ikut berperan dalam meningkatkan kualitas dan produktivitas sumber daya manusia (Depkes RI, 2004).

Salah satu upaya dalam mewujudkan pembangunan kesehatan ditempuh melalui peningkatan sumberdaya manusia dengan perhatian khusus pada kelompok rentan permasalahan kesehatan gigi dan mulut. Ibu hamil merupakan salah satu kelompok rentan yang menjadi sasaran prioritas dalam pelayanan asuhan kesehatan gigi dan mulut (Depkes, 1995).

Pada saat terjadi kehamilan, terjadi pola perubahan dalam pemeliharaan kebersihan gigi dan mulut menajadi lebih buruk. Perubahan ini disebabkan oleh timbulnya perasaan mual, muntah, perasaan takut ketika menggosok gigi karena timbulnya perdarahan gusi atau ibu terlalu lelah dengan kehamilannya sehingga ibu malas menggosok gigi. Keadaan ini dengan sendirinya akan menambah penumpukan plak sehing-ga memperburuk keadaan (Maulana, 2009). Kondisi ini akan mengakibatkan jaringan gusi mudah terse-rang infeksi. Serangan itu akan berlanjut menyerang jaringan antara akar gigi dan dinding alveolus (cekungan tempat gigi tertanam dalam tulang rahang). Berlanjut dengan pembengkakan di dalam dan di luar mulut dan bila di biarkan lama-lama gigi akan goyang dan akhirnya tak bisa ditolong dan harus dicabut (Machfoedz, 2008).

Pada masa kehamilan, diharapkan ibu hamil dapat melakukan perawatan dan pencegahan sedini mungkin terhadap kesehatan gigi dan mulut, yaitu dengan menyikat gigi sehabis makan, sebelum tidur malam, dan rajin periksa gigi guna mengetahui keadaan dan kondisi rongga mulut pada ibu hamil. Pengetahuan merupakan faktor dominan yang sangat penting dalam membentuk tindakan seseorang. Menurut pengalaman dan penelitian menyatakan perilaku yang didasari oleh pengetahuan akan lebih langgeng dari pada perilaku yang tidak di dasari oleh pengetahuan (Notoatmodjo, 2003 dalam Prasetya, 2012).

Hasil studi pendahuluan yang dilakukan pada $10 \mathrm{ibu}$ hamil di Kelurahan Bintoro secara acak pada saat kegiatan rutin posyandu diperoleh nilai rata-rata OHI-S adalah 3,3 yang berarti termasuk dalam kategori buruk. Selain itu juga diperoleh data yang menyebutkan bahwa $70 \%$ ibu hamil tidak mengetahui kapan saat sikat gigi yang tepat, $60 \%$ ibu hamil tidak mengetahui bahwa didalam masa kehamilan ada perubahan hormonal. melalui studi pendahuluan juga didapatkan data yang menunjukan sebanyak $80 \%$ ibu hamil tidak melakukan tindakan menyikat gigi secara rutin pada malam hari sebelum tidur.

Berdasar pada adanya permasalahan pengetahuan cara pemeliharaan kebersihan gigi dan mulut, perilaku menjaga kebersihan gigi dan mulut ibu hamil dan permasalahan kondisi kebersihan gigi dan mulut, maka penulis tertarik untuk melakukan penelitian mengenai pengaruh tingkat pengetahuan tentang menyikat gigi, perilaku menjaga kebersihan gigi dan mulut terhadap derajat kebersihan gigi dan mulut pada ibu hamil di Kelurahan Bintoro Kabupaten Demak.

Tujuan umum untuk mengetahui pengaruh umur kehamilan, tingkat pengetahuan tentang menyikat gigi, terhadap derajat kebersihan gigi dan 
mulut pada ibu hamil di Kelurahan Bintoro Kabupaten Demak. Tujuan khusus untuk mengetahui keadaan umur kehamilan; mengetahui tingkat pengetahuan tentang menyikat gigi

\section{METODE PENELITIAN}

Jenis penelitian yang digunakan adalah deskriptif kuantitatif dengan metode pendekatan penelitian yang digunakan adalah cross sectional. Populasi dalam penelitian adalah keseluruhan ibu hamil Kelurahan Bintoro, Kecamatan Demak, Kabupaten Demak yang memiliki usia kehamilan trimester II dan trimester III berjumlah 80 orang. Dalam penelitian ini sampel yang diambil peneliti sejumlah 55 orang. pada ibu hamil di Kelurahan Bintoro, dan mengetahui derajat kebersihan gigi dan mulut pada ibu hamil di Kelurahan Bintoro.

Pengambilan sampel dilakukan cara Proportional Stratified Random Sampling .

Pengambilan data dilakukan pada waktu posyandu. Peneliti melakukan pemeriksaan OHI-S pada reponden setelah pengisian kuesioner selesai. Analisa data dilakukan secara deskriptif kuantitatif, dilanjutkan dengan uji korelasi dan regresi. Uji korelasi dilakukan dengan rank spearman, sedangkan uji regresi dilakukan dengan regresi linear.

\section{HASIL PENELITIAN.}

Penelitian tentang pengaruh ting-kat pengetahuan menyikat gigi, peri-laku cara menjaga kebersihan gigi dan mulut terhadap derajat kebersihan gigi dan mulut pada ibu hamil di kelurahan Bintoro Kabupaten Demak .

Keadaan Umur kehamilan Ibu Hamil di Kelurahan Bintoro

Tabel 4.1.

Distribusi Frekuensi usia kehamilan pada Ibu Hamil.

\begin{tabular}{|c|l|c|c|}
\hline NO & Usia kehamilan & f & $\%$ \\
\hline 1 & Trimester II & 26 & 47,3 \\
\hline 2 & Trimester III & 29 & 52,7 \\
\hline \multicolumn{2}{|l|}{ Jumlah } & 55 & 100.0 \\
\hline
\end{tabular}

Berdasarkan tabel 4.1 usia keha-milan pada ibu hamil menunjukan bahwa usia kehamilan trimester III 29 orang $(52,7 \%)$, prosentasenya lebih besar dibanding dengan usia kehamilan trimester II 26 orang (47,3\%). Keadaan tingkat pengetahuan Ibu Hamil di Kelurahan Bintoro 
Tabel 4.2.

Distribusi Frekuensi Pengetahuan Menyikat Gigi Ibu Hamil

\begin{tabular}{|c|l|c|c|}
\hline NO & \multicolumn{1}{|c|}{$\begin{array}{c}\text { KATEGORI } \\
\text { PENGETAHUAN }\end{array}$} & $\mathrm{f}$ & $\%$ \\
\hline 1 & Buruk & 24 & 43,6 \\
\hline 2 & Baik & 31 & 56,4 \\
\hline \multicolumn{2}{|l|}{ Jumlah } & 55 & 100.0 \\
\hline
\end{tabular}

Berdasarkan tabel 4.2 pengeta-huan menyikat gigi pada ibu menunjukan bahwa tingkat penge-tahuan kategori baik 31 orang $(56,4 \%)$, prosentasenya lebih besar diban-ding dengan tingkat pengetahuan kategori buruk 24 orang $(43,6 \%)$. Keadaan derajat kebersihan gigi dan mulut pada Ibu Hamil di Kelurahan Bintoro

Tabel 4.3.

Distribusi Frekuensi derajat kebersihan gigi dan mulut Ibu Hamil

\begin{tabular}{|l|l|l|l|}
\hline NO & $\begin{array}{l}\text { Kategori derajat } \\
\text { kebersihan gigi }\end{array}$ & $\mathrm{f}$ & $\%$ \\
\hline 1 & Baik & 23 & 41,8 \\
\hline 2 & Sedang & 25 & 45,5 \\
\hline 3 & Buruk & 7 & 12,7 \\
\hline Jumlah & 55 & 100,0 \\
\hline
\end{tabular}

Berdasarkan tabel 4.3 menun-jukan bahwa hasil pemeriksaan derajat kebersihan gigi dan mulut ibu hamil dengan kategori OHI-S sedang sebanyak 25 orang $(45,5 \%)$ prosentasenya paling besar dibanding dengan kategori OHI-S baik 23 orang $(41,8 \%)$ dan buruk 7 orang $(12,7 \%)$.

1. Hubungan umur kehamilan dengan derajat kebersihan gigi dan mulut pada Ibu Hamil

Tabel 4.4.

Tabulasi Silang antara umur kehamilan dengan derajat kebersihan gigi dan mulut pada Ibu Hamil

\begin{tabular}{|c|c|c|c|c|c|c|c|}
\hline \multirow[t]{3}{*}{ NO } & \multirow{3}{*}{$\begin{array}{l}\text { KEADAAN } \\
\text { UMUR }\end{array}$} & \multicolumn{6}{|c|}{ KATEGORI OHIS } \\
\hline & & \multicolumn{2}{|c|}{ Buruk } & \multicolumn{2}{|c|}{ Sedang } & \multicolumn{2}{|l|}{ Baik } \\
\hline & & $\mathrm{f}$ & $\%$ & $\mathrm{f}$ & $\%$ & $\mathrm{f}$ & $\%$ \\
\hline 1 & TRIMESTER II & 4 & 57 & 12 & 48 & 10 & 44 \\
\hline 2 & TRIMESTER III & 3 & 43 & 13 & 52 & 13 & 56 \\
\hline & Total & 7 & 100 & 25 & 100 & 23 & 100 \\
\hline
\end{tabular}

p.value $=0,694$

Berdasarkan tabel 4.4 diperoleh data yang menunjukan bahwa untuk OHIS kategori buruk banyak berasal dari umur kehamilan trimester II sebanyak 4 orang 
(57,1 \%), dibanding dengan usia kehamilan trimester III sebanyak 3 orang (42,9 $\%)$.

Untuk OHIS kategori sedang banyak berasal dari umur kehamilan trimester III sebanyak 13 orang (52,0 \%), dibanding dengan usia keha-milan trimester II sebanyak12 orang $(48,0 \%)$.

Pada OHIS kategori baik banyak berasal dari umur kehamilan trimester III sebanyak 13 orang (56,5\%), dibanding dengan usia kehamilan trimester II sebanyak 10 orang $(43,5 \%)$.

Hasil uji korelasi dengan rank spearman dengan CI $95 \% \quad(\alpha=0,05)$, didapatkan .value $=0,694$, dikare-nakan p.value $>\alpha$ maka dapat dinterprestasikan tidak ada hubungan yang bermakna antara umur dengan derajat kebersihan gigi dan mulut.

2. Hubungan Pengetahuan Menyikat Gigi dengan derajat kebersihan gigi dan mulut pada Ibu Hamil

Tabel 4.5.

Tabulasi Silang,

Pengetahuan Menyikat Gigi dengan derajat kebersihan gigi dan mulut pada Ibu

Hamil

\begin{tabular}{|c|c|c|c|c|c|c|c|}
\hline \multirow[t]{3}{*}{ NO } & \multirow{3}{*}{$\begin{array}{c}\text { KEADAAN } \\
\text { PENGETAHUAN }\end{array}$} & \multicolumn{6}{|c|}{ KATEGORI OHIS } \\
\hline & & \multicolumn{2}{|c|}{ Buruk } & \multicolumn{2}{|c|}{ Sedang } & \multicolumn{2}{|l|}{ Baik } \\
\hline & & $\mathrm{f}$ & $\%$ & $\mathrm{f}$ & $\%$ & $\mathrm{f}$ & $\%$ \\
\hline 1 & Buruk & 5 & 71 & 19 & 76 & 0 & 0 \\
\hline 2 & Baik & 2 & 29 & 6 & 24 & 23 & 100 \\
\hline & Total & 7 & 100 & 25 & 100 & 23 & 100 \\
\hline
\end{tabular}

p.value $=0,000$

Berdasarkan tabel 4.5 diperoleh data yang menunjukan bahwa untuk OHIS kategori buruk banyak berasal dari tingkat pengetahuan buruk 5 orang $(71,4 \%)$, dibanding dengan pengetahuan baik 2 orang $(28,6 \%)$.

Untuk OHIS kategori sedang banyak berasal dari responden dengan pengetahuan buruk 19 orang (76\%), dibanding dengan pengetahuan baik 6 orang $(24 \%)$.

3. Pengaruh antara Pengetahuan Menyikat Gigi terhadap derajat kebersihan gigi dan mulut

Tabel 4.4

Hasil uji pengaruh antara tingkat pengetahuan terhadap derajat kebersihan gigi dan mulut

\begin{tabular}{|l|r|r|r|r|r|}
\hline \multirow{2}{*}{$\begin{array}{l}\text { VARIABEL } \\
\text { INDEPEN- }\end{array}$} & \multicolumn{2}{|c|}{$\begin{array}{l}\text { Unstandardized } \\
\text { Coefficients }\end{array}$} & & \multicolumn{2}{|c|}{$\begin{array}{r}95.0 \% \text { Confidence Interval } \\
\text { for B }\end{array}$} \\
\cline { 2 - 3 } \cline { 5 - 6 } & \multicolumn{1}{|c|}{ B } & Std. Error & Sig. & Lower Bound & Upper Bound \\
\hline $\begin{array}{l}\text { PENGETAHU } \\
\text { AN }\end{array}$ & -.135 & .029 & .000 & -.194 & -.077 \\
\hline
\end{tabular}


Dengan melihat hasil uji regresi linear dengan $\mathrm{CI}=95 \%$ $(\alpha=0,05)$, didapat $p$.value $=0,000$, hasil penelitian menunjukan p.value $<0,05$ sehingga dinterprestasikan terdapat pengaruh yang bermakna antara pengetahuan terhadap derajat kebersihan gigi dan mulut.

\section{PEMBAHASAN}

Keadaan derajat kebersihan gigi dan mulut, yang dilakukan dengan indikator pemeriksaan OHIS, masih dijumpai keadaan OHIS dengan kategori sedang dan buruk. Adanya keadaan OHIS yang belum optimal tersebut menunjukan bahwa belum sepenuhnya ibu hamil bisa melakukan cara-cara menjaga pemeliharaan kebersihan gigi dan mulut. Keadaan ini sangat dimungkinkan pada ibu hamil dikarenakan banyaknya gangguan yang sering terjadi pada ibu hamil salah satunya adalah rasa mual. Hasil penelitian juga menunjukan bahwa responden malas memelihara kebersihan gigi dan mulut.

Hasil penelitian mengenai hubungan keadaan umur kehamilan dengan derajat kebersihan gigi dan mulut menunjukan bahwa untuk OHIS kategori buruk banyak berasal dari umur kehamilan trimester II, OHIS kategori sedang banyak berasal dari umur kehamilan trimester III, dan OHIS kategori baik banyak berasal dari umur kehamilan trimester III. Melihat distribusi hasil penelitian menunjukan bahwa semakin usia kehamilan meningkat diikuti dengan derajat kebersihan gigi dan mulut yang meningkat, namun secara statistik menunjukan tidak ada hubungan antara umur kehamilan dengan derajat kebersihan gigi dan mulut. sebagaimana hasil uji korelasi dengan rank spearman dengan CI $95 \%$ $(\alpha=0,05)$, didapatkan p.value $=0,694$, dikarenakan p.value $>\alpha$ maka dapat dinterprestasikan tidak ada hubungan yang bermakna antara umur dengan derajat kebersihan gigi dan mulut.

Tidak adanya hubungan antara umur kehamilan dengan derajat kebersihan gigi dan mulut besar kemungkinan disebabkan bahwa secara umum dalam fase usia kehamilan keadaan atau kondisi ibu hamil dalam keadaan mengalami gangguan hormonal sehingga berakibat pada cara pemeliharaan kesehatan gigi yang mengalami gangguan dikarenakan adanya perasaan tidak nyaman seperti timbul-nya rasa mual.

Keadaan ini seperti yang disampaikan Maulana (2009) bahwa pada ibu hamil terjadinya perubahan pemeliharaan kebersihan gigi dan mulut yang sebabkan timbulnya gangguan sewaktu hamil (mual) menjadikan ibu hamil malas menggosok gigi. Kondisi inilah yang semakin memperburuk keadaan

Hasil penelitian mengenai hubungan antara pengetahuan dengan derajat kebersihan gigi dan mulut menunjukan bahwa untuk OHIS kategori buruk banyak berasal dari tingkat pengetahuan buruk, dan untuk OHIS kategori baik banyak berasal dari responden dengan pengetahuan baik. Adanya keadaan ini menunjukan bahwa ada hubungan antara pengetahuan dengan derajat kebersihan gigi dan mulut (OHIS). Keadaan ini didukung dengan hasil uji korelasi dengan rank spearman dengan p.value $=0,000$, dinterprestasikan terdapat hubungan yang bermakna antara pengetahuan dengan derajat kebersihan gigi dan mulut. 
Hasil penelitian menunjukan bahwa masih dijumpai pengetahuan responden dengan kategori kurang. Adanya pengetahuan yang masih kurang tentu saja akan menjadikan kesadaran responden untuk memelihara kebersihan gigi menjadi tidak terwujud. Dengan tidak terwujudnya kesadaran akan berdam-pak pada tidak timbulnya rasa ketertarikan responden dalam hal cara-cara pemeliharaan kebersihan gigi. Sehingga dengan tidak terpenuhinya pengetahuan yang cukup pada responden tentu saja akan beredampak pada tidak terjadinya proses adopsi perilaku baru sebagaimana disampaikan dalam teori adopsi perilaku oleh yang diawali dengan awernes, interest, evalution, trial, adoption (Notoadmodjo, 2012).

Pengetahuan yang belum optimal akan berpengaruh terhadap derajat kebersihan gigi dan mulut. Pengetahuan yang masih buruk akan menjadikan responden tidak mempunyai bekal yang cukup untuk merubah sikap seseorang. Adanya perubahan sikap positip yang tidak terbentuk pada diri seseorang akan menjadikan tidak terwujudnya perilaku baru.

Sesuai dengan ungkapan Notoatmodjo (2007) yang menyatakan bahwa seseorang yang memiliki peningkatan pengetahuan akan bersikap mendukung dan akan tercermin dalam bentuk tindakan atau tingkah laku yang lebih baik.

\section{KESIMPULAN}

Berdasarkan dari hasil penelitian Pengaruh Tingkat Pengetahuan Menyikat Gigi terhadap OHI-S pada Ibu Hamil di Kelurahan Bintoro Kabupaten Demak yang telah dilaksanakan bulan Mei 2013 di
Posyandu Kelurahan Bintoro pada 55 responden, dapat diambil kesimpulan sebagai berikut:

1. Kedaan umur kehamilan ibu sebagian besar dalam kelompok trimester III 29 orang (52,7 \%).

2. Tingkat pengetahuan responden sebagian besar dalam kondisi kategori baik 40 orang $(60,6 \%)$.

3. Derajat kebersihan gigi dan mulut ibu hamil sebagian besar dalam kategori OHI-S sedang 25 orang $(37,9 \%)$.

4. Ada hubungan yang bermakna antara pengetahuan dengan derajat kebersihan gigi dan mulut, sesuai hasil uji korelasi dengan rank spearman dengan CI $95 \%(\alpha=0,05)$, didapatkan p.value $=0,000$.

5. Ada pengaruh yang bermakna antara pengetahuan terhadap derajat kebersihan gigi dan mulut, sesuai hasil uji regresi linear dengan $\mathrm{CI}=$ $95 \%(\alpha=0,05)$, didapat p.value $=$ 0,000 .

\section{SARAN}

Sehubungan dengan hasil penelitian tentang pengaruh tingkat pengetahuan menyikat gigi terhadap OHI-S pada ibu hamil di Kelurahan Bintoro Kabupaten Demak, maka penulis memberikan saran sebagai berikut :

1. Kepada ibu hamil disarankan untuk selalu menjaga dan meningkatakan pemeliharaan kebersihan gigi pada semua fase umur kehamilan, dikarena pada setiap tahapan trimester kehamilan sama-sama rentan dalam permasalahan pemeliharaan kebersihan gigi.

2. Kepada ibu hamil untuk lebih meningkatkan dengan beberapa cara seperti mengikuti kegiatan 
penyuluhan oleh tenaga kesehatan, membaca leaflet atau mealui media lain secara cetak dan elektronik.

3. Kepada ibu hamil disarankan untuk menjaga dan meningkatkan cara $=$ cara memelihara kebersihan gigi dan mulut dengan harapan derajat kebersihan bisa meningkat.

4. Perlu dilakukan penelitian lebih lanjut mengenai pengaruh pengetahuan, sikap dan tindakan terhadap tingkat kebersihan gigi dan mulut.

\section{DAFTAR RUJUKAN}

Depkes RI, 1995, Pedoman Pelayanan Kesehatan Gigi dan Mulut Ibu Hamil, Ibu Menyusui, Balita dan Anak Prasekolah Secara Terpadu di RSU dan Puskesmas, Jakarta.

Depkes RI, (2004), Pedoman Upaya Kesehatan Gigi Masyarakat (UKGM), Depkes RI: Jakarta.

Herijulianti, E.,Indriani,TS., Artini,S., 2002, Pendidikan Kesehatan Gigi, EGC: Jakarta

Jogianto, HM, 2005, Analisis dan Desain Sistem Informasi, Andi: Yogyakarta.

Machfoedz, I., 2010, Metodologi Penelitian Kuantitatif \& Kualitatif Bidang Kesehatan, Keperawatan, Kebidanan, Kedokteran, Penerbit Fitramaya: Yogyakarta.

Machfoedz, I., (2008), Menjaga Kesehatan Gigi dan Mulut Anak-anak dan Ibu Hamil, Penerbit Fitramaya: Yogyakarta.
Manuaba, I B G., 1998, Ilmu Kebidanan, Penyakit Kandungan Dan Keluarga Berencana Untuk Pendidikan Kebidanan, EGC: Jakarta

Maulana, M., 2009, Cara Cerdas Menghadapi Kehamilan Dan Mengasuh Bayi, Katahati: Yogyakarta

Notoatmodjo, S, (2003), Ilmu Kesehatan Masyarakat Prinsip - Prinsip Dasar, Penerbit Rineka Cipta: Jakarta.

Notoatmodjo, S., 2005, Promosi Kesehatan Teori Dan Aplikasinya, Penerbit Rineka Cipta: Jakarta.

Notoatmodjo, S., 2010, Metodologi Penelitian Kesehatan, Edisi Revisi, Rineka Cipta: Jakarta

Notoatmodjo, S., 2012, Promosi Kesehatan dan Perilaku Kesehatan, Penerbit Rineka Cipta: Jakarta

Pratiwi, D.,2007, Gigi Sehat Merawat Gigi Sehari-hari, Penerbit Buku Kompas: Jakarta, hal 46-58.

Solahuddin, G, (2010), Ibu Hamil Jangan Lupa Merawat Gigi. http://www. Tabloidnova.com/Nova/Kesehatan/Wan ita/Ibu-Hamil-Jangan-LupaMerawat-Gigi Diakses tanggal 12 Juli 2013.

Sriyono, N.W.,2005, Pengantar Ilmu Kedokteran Gigi Pencegahan, Penerbit Medika Fakultas Kedokteran UGM: Yogyakarta

Undang-Undang Republik Indonesia Nomor 36 Tahun 2009 Tentang Kesehatan. 